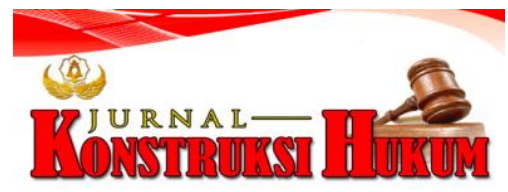

\title{
AKIBAT HUKUM BAGI PRAJURIT TNI MELAKUKAN TINDAK PIDANA DESERSI YANG DIPUTUS IN ABSENTIA DALAM PRAKTEK PENGADILAN MILITER III-14 DENPASAR
}

\author{
I Wayan Kusuma Purwanta, I Anak Agung Sagung Laksmi Dewi, Ni Made Sukaryati Karma \\ Fakultas Hukum Universitas Warmadewa, Denpasar-Bali, Indonesia
}

\begin{abstract}
Abstrak
Negara Kesatuan Republik Indonesia adalah Negara Hukum. Wajib bagi warga Negara Indonesia taat dan tunduk kepada hukum tidak terkecuali bagi Prajurit Tentara Nasional Indonesia. Prajurit Tentara Nasional Indonesia disamping tunduk kepada aturan-aturan hukum yang bersifat umum seperti Kitab Undang-Undang Hukum Pidana (KUHP) dan juga tunduk kepada aturan-aturan yang bersifat khusus yang hanya berlaku bagi prajurit Tentara Nasional Indonesia yaitu Kitab Undang-Undang Hukum Pidana Militer (KUHPM) dan Kitab Undang-Undang Hukum Disiplin Militer (KUHDM). Sikap disiplin merupakan tonggak dasar bagi prajurit TNI dalam melaksanakan tugasnya. Apabila seorang Prajurit TNI kurang disiplin dalam Tata kehidupannya akan memicu terjadinya suatu tindak pidana. Penelitian ini bertujuan untuk menjelaskan faktor faktor penyebab prajurit TNI melakukan tindak pidana desersi dan menjelaskan akibat hukum dari putusan In Absentia bagi prajurit TNI yang melakukan tindak pidana Desersi. Metode yang dipergunakan adalah metode penelitian yuridis-empiris dengan pendekatan masalah menggunakan studi kasus yang berdasarkan kejadian asli di lapangan tanpa adanya suatu pengelabuan dan bersifat murni. Bahan hukum yang digunakan adalah bahan hukum primer dan bahan hukum sekunder. Hasil penelitian menyebutkan bahwa akibat hukum In absentia seorang prajurit TNI yang melakukan tindak pidana Desersi akan tetap disidang tanpa hadirnya terdakwa dan dijatuhi pidana penjara dengan pidana tambahan berupa pemecatan dari dinas militer dan faktor penyebab prajurit TNI melakukan tindak pidana Desersi adalah kurangnya disiplin sebagai prajurit militer, ekonomi hidup pas pasan, terlibat suatu tindak pidana, terlilit banyak hutang dan pengaruh pergaulan lingkungan.
\end{abstract}

Kata Kunci: Desersi; In Absentia; Disiplin Militer

\begin{abstract}
The Unitary State of the Republic of Indonesia is a State of Law. Obligatory for Indonesian citizens to obey and obey the law, no exception for Soldiers of the Indonesian National Army. Apart from being subject to general legal rules such as the Criminal Code and also subject to special rules that only apply to soldiers of the Indonesian National Army, namely the Military Criminal Code and the Military Discipline Law Code. Discipline attitude is a basic milestone for TNI soldiers in carrying out their duties. If a TNI soldier lacks discipline in his life, it will lead to a criminal act. This study aims to explain the factors that cause TNI soldiers to commit the Esersion crime and to explain the legal consequences of the In Absentia decision for TNI soldiers who commit the crime of desertion. The method used is a juridical-empirical research method with a problem approach using case studies that are based on real events in the field without any deception and are pure in nature. The legal materials used are primary and secondary legal materials. The results of the study state that the legal consequence of In absentia a TNI soldier who commits the crime of desertion will remain on trial without the presence of the defendant and will be sentenced to imprisonment with additional penalties in the form of dismissal from military service and the factor that causes TNI soldiers to commit the crime of desertion is lack of discipline as a military soldier, the economy barely lives, is involved in a criminal act, is in debt and is influenced by environmental associations.
\end{abstract}

Keywords: Desertion; In Absentia; Military Discipline

\section{PENDAHULUAN}

Negara Indonesia merupakan negara yang berkembang dengan keunikan budaya yang multikultur serta kehidupan masyarakat yang berpatokan pada ideologi negara yaitu Pancasila. Eksistensi Pancasila menjadi cerminan bangsa yang beradab dan bermartabat sesuai dengan konsep ketuhanan kemanusiaan persatuan demokrasi dan keadilan. Nilai-nilai yang terkandung dalam Pancasila memberikan dorongan terciptanya konstitusi dasar Negara Indonesia yang disebut sebagai UndangUndang Dasar Negara Kesatuan Republik Indonesia tahun 1945 (UUD NRI 1945). Dalam konstitusi 
dasar Negara memuat ketentuan-ketentuan umum mengenai segala hal yang berkaitan dengan negara. Salah satunya adalah mengenai Hak Asasi Manusia (HAM). Menurut Arief, (2014) Negara kesatuan republik Indonesia adalah Negara yang berlandaskan pada hukum, jadi setiap warga Negara Indonesia taat dan tunduk kepada hukum tidak terkecuali bagi para prajurit Tentara Nasional Indonesia dikenal dengan sikap disiplinnya. Disiplin merupakan nafas dari seorang Tentara Nasional Indonesia. Tanpa disiplin seorang prajurit tidak ada bedanya dengan segerombolan bersenjata yang akan menjadi pengacau sebuah negara. Menurut Aggasi \& Ningtiyas, (2019) Sikap disiplin merupakan tonggak dasar bagi prajurit TNI dalam melaksanakan tugasnya. Apabila seorang Prajurit TNI kurang disiplin dalam tata kehidupannya akan dapat sebagai penyebab terjadinya suatu tindak pidana (Sulistiriyanto, 2011).

Dalam kehidupannya setiap prajurit TNI memiliki kode etik dalam pergaulan sehari-hari abaaba kehormatan dalam perjuangan aba-aba moral perihal perilaku dan pengalaman dan struktur nilai dalam kaidah kehidupan sehari-hari yang keren. Menurut Faisal, (2005) bahwa hakikat disiplin prajurit yaitu:

1. Perihal kepatuhan

Perihal kepatuhan yang dilandasi sebab kesadaran lahir dan batin ialah manifestasi penanganan diri untuk tidak melanggar perintah kedinasan dan tata kehidupan prajurit.

2. Perihal prajurit

Perihal prajurit Angkatan Perang Tentara Republik Indonesia tetap mematuhi perintah dan tunduk pada hukum yang berlaku baik di dalam organisasi maupun dalam masyarakat nantinya

Disamping itu seorang prajurit harus memiliki disiplin prajurit yang tinggi sebagaimana yang diatur dalam aturan hukum dalam kaedah undang-undang TNI. Sikap disiplin mutlak ditanamkan bagi prajurit TNI dikarenakan mereka lah garda terdepan yang mempunyai kewenangan untuk menjaga kedaulatan dan keamanan dari kejahatan maupun ancaman dari negara asing yang memasuki wilayah kedaulatan Negara Kesatuan Republik Indonesia, terutama sekali dalam kawasan Zona Ekonomi Eksklusif (ZEE) yaitu batas zona luasnya 200 mil dari garis bibir pantai. Tentu itu merupakan hal yang penting karena kawasan dari NKRI sebagaian wilayahnya merupakan sektor maritim dan tentu hasil laut merupakan salah satu mata pencaharian yaitu nelayan. Sebagai warga Indonesia tentu kita tidak mau hasil alam kita di rampas secara illegal oleh kapal negara asing, maka dibutuhkan garda terdepan ini untuk menjaga keanekaberagaman hasil laut ini agar seutuhnya bisa dinikmati oleh warga Indonesia.

Masyarakat dianggap tidak perlu mengetahui peran dan tata cara penuntutan dari Oditur Militer tersebut. Jika ditelaah kembali penegakan hukum (law enforcement) seyogianya harus terbuka untuk umum karena untuk menjamin apakah hal yang dilakukan oleh penegak hukum di lingkungan militer tersebut sudah benar dengan ketentuan peraturan perundang-undangan yang ada dan telah dilakukan secara objektif dalam proses penuntutan serta penerapan hukum dalam tindak desersi yang dilakukan oleh anggota militer.

Penelitian terdahulu mengungkapkan bahwa anggoota militer yang melakukan tindak pidana desersi tetap ditindak dilaksanakan supaya perkara tersebut dapat diselesaikan dengan cepat demi tegaknya disiplin prajurit dalam rangka menjaga keutuhan pasukan, termasuk dalam hal ini pelimpahan perkara yang terdakwanya tidak pernah diperiksa karena sejak awal melarikan diri dan tidak diketemukan lagi dalam jangka waktu 6 (enam) bulan berturut-turut, untuk keabsahannya harus dikuatkan dengan surat keterangan dari Komandan atau Kepala Kesatuannya. Penghitungan tenggang waktu 6 (enam) bulan berturut- turut terhitung mulai tanggal pelimpahan berkas perkaranya ke Pengadilan (Sugistiyoko, 2018). Penelitian lain (Sari, 2015) Prajurit yang tidak memenuhi peraturanperaturan yang ada maka prajurit tersebut disebut melakukan tindak pidana dan akan diproses sesuai dengan ketentuan yang berlaku. Sedangkan hambatan atau kendala Pengadilan Militer dalam mengungkap fakta-fakta hukum untuk memutus secara in absensia dipengaruhi oleh faktor personal, faktor dalam peraturan, faktor prosedur penyidikan, pemeriksaan, dan eksekusi di pengadilan (Satyastuti et al., 2016). Oleh karena itu penelitian ini dilakukan bertujuan untuk menjelaskan faktor faktor penyebab prajurit TNI melakukan tindak pidana desersi da menjelaskan akibat hukum dari putusan In Absentia bagi prajurit TNI yang melakukan tindak pidana Desersi.

\section{METODE PENELITIAN}


Penelitian ini menggunakan metode penelitian yuridis empiris yaitu suatu metode yang mengkaji hukum yang diterapkan/diimplementasikan di dalam masyarakat. Sedangkan pendekatan masalah menggunakan studi kasus yang berdasarkan kejadian asli di lapangan tanpa adanya suatu pengelabuan dan bersifat murni. Bahan hukum yang digunakan adalah bahan hukum primer dan bahan hukum sekunder. Metode yang digunakan dalam pengumpulan bahan hukum dengan cara studi kepustakaan (library research) yaitu suatu cara untuk mengumpulkan data yang bersifat teoritis dari beberapa buku ilmiah atau bacaan yang dapat dipertanggungjawabkan kebenarannya dan observasi/pengamatan yaitu melakukan pengamatan untuk memperoleh data dan informasi secara langsung ke objek penelitian yaitu melalui wawancara. Setelah diperoleh data-data yang berhubungan dengan permasalahan maka data tersebut akan diolah serta secara kualitatif yaitu dengan mendeskrisipkan yang cenderung melalui analisisi suatu persfektif subjek yang lebih mencolok (Sugiyono, 2005).

\section{HASIL DAN PEMBAHASAN}

\section{Faktor-Faktor Penyebab Prajurit TNI Melakukan Tindak Pidana Desersi}

Dalam beberapa literatur hukum pidana pengertian tindak pidana disamakan dengan delik atau perbuatan pidana. Perbuatan pidana adalah perbuatan yang tidak boleh dilanggar dan apabila dilanggar akan dikenakan sanksi sesuai aturan tertulis yang berlaku. Menurut Jonaedi, (2015) Tindak pidana desersi merupakan tindak pidana militer yang pada umumnya terdapat dalam KUHPM yang dibagi dalam dua bagian yaitu Tindak pidana militer murni yaitu suatu perbuatan yang murni atas kesalahan dari anggota militer baik yang disengaja maupun yang tidak disengaja. Walaupun begitu karena hal yang darurat pun dalam sebuat etis profesional seorang anggota militer apabila tetap melanggar ya tetap dikenakan sanksiTindak pidana militer campuran adalah tindakan yang dilarang yang sudah ada pokok yang ditentukan oleh undang-terjadi sesuatu hal yang karena adanya sifat tertentu maka diperlukan ancaman pidana yang lebih berat dari kejahatan lainnya (Suratman \& Dillah, 2015).

Selain itu, para anggota militer bisa bertindak anarkis padahal hal tersebut dilarang oleh etika kemiliteran, sama seperti halnya dengan kepolisian yaitu menciptakan keamanan kedaultan NKRI, namun tugas dari seorang Tentara Republik Indonesia. Berhubungan dengan itu Jika ditelaah kembali penegakan hukum seyogianya harus terbuka untuk umum karena untuk menjamin (law enforcement) apakah hal yang dilakukan oleh penegak hukum di lingkungan militer tersebut sudah benar dengan ketentuan peraturan perundang-undangan yang ada dan telah dilakukan secara objektif dalam proses penuntutan serta penerapan hukum dalam tindak desersi yang dilakukan oleh anggota militer.

Berdasarkan data yang diperoleh melalui wawancara dari beberapa pegawai di Kantor Oditurat Militer III-13 Denpasar dan di Kantor Pengadilan Militer III-14 Denpasar peneliti menemukan berbagai bentuk faktor penyebab prajurit TNI melakukan tindak pidana desersi antara lain:

a. Wawancara dengan

1) Terlibat perselingkuhan atau mempunyai wanita idaman lain

2) Mempunyai banyak hutang

3) Akibat kekerasan dalam rumah

4) Akibat kekerasan dalamr umah tangga (KDRT)

5) Kurang disiplin.

b. Wawancara dengan Bapak Letnan Kolonel Chk Tarmizi Oditur Militer III-13 Denpasar pada tanggal 10 Februari 2020 mengatakan bahwa yang menjadi faktor penyebab prajurit TNI melakukan tindak pidana desersi yaitu:

1. Dipengaruhi oleh faktor mental yaitu secara sederhanadapat dipahami sebagai sesuatu yang berhubungan dengan batin dan watak atau karakter tidak bersifat jasman

2. Dipengaruhi oleh factor kurangnya disiplin seorang prajurit

3. Karena keadaan ekonomi yang miskin

4. Banyak mempunyai hutang

5. Dipengaruhi pergaulan lingkungan; 


\section{Akibat Hukum Dari Putusan In Absentia Bagi Prajurit TNI yang Melakukan Tindak Pidana Desersi}

Dalam sebutan hukum pengadilan in absentia adalah menjadi jalan untuk memeriksa seseorang dan menghukumnya walaupun kehadiran terdakwa dari perkara tersebut beliau tidak hadir. Dalam pemahaman In absentia yaitu pemeriksaan yang dilakukan agar permasalahan hukum tersebut dapat diakhiri dengan cepat tatkala untuk teguhnya disiplin dalam rangka melindungi integritas kesatuan termuat apabila terdakwa tidak hadir atau melarikan diri atau memang tidak bisa diketemukan sosoknya dalam kurun 6 (enam) bulan diusahakan agar hadir dan sudah berulang kali di panggil dalam prosesi persidangan dalam kurun 3 (tiga) kali berturut turut apabila tersedia di persidangan minus sebuah dalil oleh sebab itu putusan dapat diputus walaupun tanpa hadirnya terdakwa. Dapa dihitung dalam kurun waktu 6 bulan dan file putusan lebih lanjut akan dibawa ke dalam persidangan untuk dibacakan putusannya oleh hakim (Aziz, 2014).

Sesuai hasil wawancara dengan Letnan Kolonel I Putu Gede Budiadi dari Oditurat Militer III13 Kota Denpasar dalam praktek pengadilan militer setelah pengadilan militer menerima pelimpahan berkas desersi dari oditurat militer (kejaksaan militer) maka tahapan-tahapan sebelum tindak pidana desersi diputuskan oleh majelis hakim dapat dilalui beberapa tahapan oleh pengadilan militer yaitu membuat rencana sidang penetapan majelis hakim dan penetapan hari sidang setelah dikeluarkan penetapan hakim oleh kepala pengadilan militer tentang susunan majelis hakim yang di tunjuk untuk menyidangkan perkara desersi yang terdiri dari satu hakim ketua dan dua hakim anggota maka hakim ketua akan mengeluarkan penetapan hari sidang untuk disampaikan kepada kepada oditurat militer (kejaksaan militer) melalui panitera pengadilan militer yang membuat perintah agar oditurat militer melakukan pemanggilan terhadap terdakwa dengan para saksi untuk hadir di persidangan pengadilan militer. Setiap orang yang melakukan suatu tindakan pidana atau melakukan perbuatan perbuatan yang melanggar hukum dapat dijatuhkan sanksi/pidana tidak terkecuali bagi seorang TNI kalau sudah terbukti melanggar akan dikenakan sanksi pidana pokok, denda, kurungan dan juga pidana tambahan contohnya, perampasan barang tertentu.

Selanjutnya wawncara dengan Dwi Chrisna Wati dari Oditurat Militer III-13 Kota Denpasar Dalam praktek peradilan militer yang dapat diputus secara In absentia adalah perbuatan pidana Desersi dimasa damai yang dimana diatur dan diancam dengan pidana dalam pasal 87 ayat (1) ke-2 ayat (2) Kitab Undang undang Hukum Pidana Militer (KUHPM) yang ancaman pidananya 2 (dua) tahun 8 (delapan) bulan.

Dari data yang diperoleh di Orditurat Militer III-13 Denpasar yang terangkum dalam laporan tahunan yaitu tahun anggaran 20172018 2019. Data perkara tindak pidana Desersi yang diterima oleh Oditurat Militer III-13 Kota Denpasar dari penyidik polisi Militer yang terdiri dari 3 (tiga) mantra yaitu penyidik polisi militer TNI-AD TNI-AL dan TNI-AU yang berada diwilayah hukum Oditurat Militer III-13 Denpasar yang meliputi Provinsi Bali dan Provinsi Nusa Tenggara Barat sebanyak 44 perkara Desersi dari 44 jumlah perkara Desersi yang diterima oleh Oditurat Militer III13 Kota Denpasar selanjutnya perkara Desersi tersebut dilimpahkan ke pengadilan militer III-14 Kota Denpasar untuk diperiksa dan diadili sesuai ketentuan hukum yang berlaku. Dalam tanggung waktu 3 (tiga) tahun tersebut yaitu dari tahun 2017 sampai tahun 2019 telah diputus secara In absentia sebanyak 33 (tiga puluh tiga) perkara.

Setelah Putusan Pengadilan Militer telah memperoleh kekuatan hukum yang tetap yaitu hari kedelapan setelah amar putusan dijatuhkan putusan oleh Majelis Hakim kepada terdakwa, selanjutnya panitera pengadilan mengirimkan Salinan putusan kepada Oditurat Militer III-13 Kota Denpasar untuk ditindak lanjuti, karena tugas oditur militer salah satunya adalah melaksanakan putusan dan penetapan pengadilan.

Oditurat Militer III-13 Kota Denpasar setelah menerima Salinan putusan perkara In absentia, sebagai pelaksanaan putusan pengadilan kemudin oditur militer memberitahukan isi dari putusan tersebut kepada ankum (atasan yang berhak menghukum) terpidana yang isinya sebagai berikut:

1. Agar ankum (atasan yang berhak menghukum) terpidana, mengajukan terpidana tersebut kepada pejabat yang berwenang untuk pemecatan terpidana secara administrativ

2. Agar ankum (atasan yang berhak menghukum) terpidana melaporkan kepada oditur militer apabila sewaktu waktu terpidana tertangkap untuk selanjutnya dieksekusi di Lembaga pemasyarakatan umum 


\section{SIMPULAN DAN SARAN}

\section{Simpulan}

Dari hasil analisis data, dapat diketahui bahwa Faktor penyebab prajurit TNI melakukan tindak pidana Desersi adalah kurangnya disiplin sebagai prajurit militer, faktor ekonomi hidup pas-pasan, terlibat terlibat suatu tindak pidana d. terlilit banyak hutang dan pengaruh pergaulan lingkungan, yang kedua akibat hukum dari putusan In absensia yaitu seorang prajurit TNI yang melakukan tindak pidana Desersi akan tetap di sidang tanpa hadirnya terdakwa putusan pengadilan militer dijatuhi pidana penjara dengan pidana tambahan berupa pemecatan dari dinas militer. Putusan pengadilan militer yang dipurus secara In absentia tetap mengikat terdakwa setelah putusan berkekuatan hukum tetap oditur militer akan memberitahukan isi putusan kepada oknum terdakwa dan apabila sewaktu-waktu berhasil ditangkap terdakwa bisa langsung dieksekusi oleh oditur militer ke Lembaga permasyarakatan umum. Bahwa walaupun terdakwa sudah dipecat oleh dinas militer berdasarkan putusan pengadilan militer pemecatan secara administratif tetap diajukan ke pimpinan TNI.

\section{Saran}

Adapun yang disarankan oleh peneliti yaitu Untuk meningkatkan moril dan semangat bagi Prajurit TNI agar atasan pimpinan TNI memperhatikan dan meningkatkan kesejahteraan bagi Prajurit Tentara Nasional Indonesia dan keluarganya, yang kedua untuk menegakkan kedisiplinan Prajurit Tentara Nasional Indonesia agar di setiap kesatuan atau institusi Tentara Nasional Indonesia secara rutin ataupun berkala melaksanakan pembinaan kepada Prajurit TNI melalui penyuluhan hukum.

\section{DAFTAR PUSTAKA}

Aggasi, A., \& Ningtiyas, F. W. (2019). Pola Komunikasi Militer dalam Program Swasembada Pangan di Wilayah Koramil 1607/-01 Sumbawa. Jurnal Tambora, 3(2), 66-74.

Arief, A. Z. H. R. (2014). Pengantar Ilmu Hukum. PT. Rajagrafindo Persada.

Aziz, S. (2014). Tindak Pidana Khusus. Sinar Grafika.

Faisal, S. M. (2005). Hukum Pidana Militer di Indonesia mandar Maju. Mandar Maju.

Jonaedi, G. I. E. (2015). Cepat dan Mudah Memahami Hukum Kencana. Prenadamedia Group.

Sari, A. M. (2015). Pemeriksaan Secara In Absensia Terhadap Pelaku Tindak Pidana Desersi dalam Waktu Damai. Jurnal Verstek, 6(3), 45-55.

Satyastuti, N. W. R., Sari, C. A. T., \& Vaundra, V. A. (2016). Proses Penyelesaian Tindak Pidana Desersi yang Dilakukan oleh Anggota Tentara Nasional Indonesia. Jurnal Verstek, 4(2), 10-17.

Sugistiyoko, O. :Bambang S. E. (2018). Tindak Pidana Desersi Secara In Absensia Anggota Militer. Hukum Pidana, 4(1), 50-79.

Sugiyono. (2005). MemahamiPenelitian Kualitatif. Alfabeta.

Sulistiriyanto, H. (2011). Pertanggungjawaban Pidana Anggota Militer yang Melakukan Tindak Pidana Desersi. 16(2).

Suratman, \& Dillah, H. P. (2015). Metode Penelitian Hukum. 